\title{
SCCが高値を示した成熟囊胞性奇形腫に対して 腹腔鏡下手術を行った2症例
}

石川県立中央病院産婦人科

前川真知子、平吹信弥、佐々木博正、干場 勉、朝本明弘

\section{Application of laparoscopic surgery for an ovarian mature cystic teratoma with an elevated SCC: Report of two cases}

\author{
Machiko Maekawa, Shinya Hirabuki, Hiromasa Sasaki, \\ Tsutomu Hoshiba, Akihiro Asamoto \\ Department of obstetrics \& gynecology, Ishikawa Prefectural Central Hospital
}

\begin{abstract}
Mature cystic teratomas are common, mostly benign ovarian tumors, which account for about $20 \%$ of all ovarian neoplasms; however, it is also known that malignant transformation occurs in approximately $1 \%$ to $2 \%$ of those cases. It has been reported that elevated squamous cell carcinoma antigen (SCC) is an indicator of the malignant potential of an ovarian mature cystic teratoma, therefore, special attention must be taken during surgery of those cases with an elevated SCC preoperatively.

We reported two cases of mature cystic teratomas with elevated SCC who underwent laparoscopic surgery. Although the SCC levels were $>5.0 \mathrm{ng} / \mathrm{ml}$ in our cases, the preoperative pelvic CT and MRI did not show any malignant characteristics.

Preventative measures were taken to avoid the potential rupture of tumors, and those tumors were resected laparoscopically without leakage of tumor content into the pelvic cavity. Histopathologic studies confirmed a benign teratoma. The SCC levels were normalized 1-2 months after surgery.

In these cases, it is controversial whether laparoscopic surgery is appropriate because of the potential interruption of capsule integrity during surgery of a possible malignant tumor when an endoscopic approach is chosen.

Laparoscopic surgery can be safely performed in cases in which if a malignant possibility is incontrovertible, intensive preoperative efforts to select less probable malignant case have been taken, and securing measures against the possible rupture of tumor is available.
\end{abstract}

キーワード：成熟囊胞性奇形腫、SCC、腹腔鏡下手術

\section{緒言}

成熟囊胞性奇形腫は全卵巣腫瘍の約 $20 \%$ 占め 頻度の高い良性腫瘍であるが、1〜 $2 \%$ 悪性転 化すると言われ、特にSCCが高値を示す場合悪性 転化の可能性を考慮した充分な検討が必要とされ ている。今回、SCCが高值を示し画像診断で成熟 䡬胞性奇形腫の所見であった症例に対し腹腔鏡下 手術を施行した 2 症例を経験したので若干の考察
を加え報告する。

\section{症 例 1}

22 歳、 1 経妊 0 経産

主 訴: 下腹部腫瘤感

既往歴 家族歴：特記事項なし

現病歴：2005年 1 月、他院にて人工妊娠中絶の際 に経腟超音波で両側卵巣囊腫を指摘され精查加療 目的に当院紹介受診した。 
身体所見：身長 $159 \mathrm{~cm}$ 体重 $70 \mathrm{~kg}$ 、腹部はやや膨満 で軟らかく自発痛や圧痛はなかった。

画像所見：超音波では両側に充実性部分を含む多 房性の腫瘍を認め左は $10 \mathrm{~cm}$ 以上あり上腹部まで達 し、右は骨盤腔に存在していた。また充害性部分 は一部乳頭状に見えた（図1）。MRIではT 1 強 調 T 2 強調ともに高信号、脂肪抑制 T 1 強調像で 信号が抑制される多房性腫瘍を認めた。造影MRI で充実部位への早期濃染はなかった。CTでは石灰 化部分もあり典型的な成熟襄胞性奇形腫の所見で 造影効果もなかった（図 2 )。

腫瘍マーカー：CA19-9 $314.7 \mathrm{U} / \mathrm{ml} 、 \mathrm{CA} 12553.0$ U/ml、SCC $5.9 \mathrm{ng} / \mathrm{ml}$ 、AFP $2.4 \mathrm{ng} / \mathrm{ml}$ 、CEA 2.2 $\mathrm{ng} / \mathrm{ml}$ 。手術所見（図 3 ）：SCCは高值であったが 若年で画像上の悪性所見にそしかったため腹腔鏡 下手術を行った。腫瘤が大きいため下腹部に $4 \mathrm{~cm}$ の横切開を加えラップディスクミニを装着して行 った。左卵巣腫瘍は直径約 $5 \mathrm{~cm}$ の囊胞 5 個ほどか ら成り、腫瘤を直視下に切開し内容を吸引し囊胞 の摘出を行った。卵巣被膜が薄く内容が多彩で長 時間を要したが腹腔内への漏出はなかった。右卵 巣にも $4 \mathrm{~cm}$ 程の囊胞が4個あり、これも直視下に 吸引し摘出した。術中迅速病理診断は良性の成熟 囊胞性奇形腫で、内面は角化型重層扁平上皮によ って被覆されていた。両側とも体外法にて卵巣を 修復し腹腔内に戻した。

\section{図 1 症例 1 の超音波所見 a.経腹超音波像 b.経腔超音波像}

a

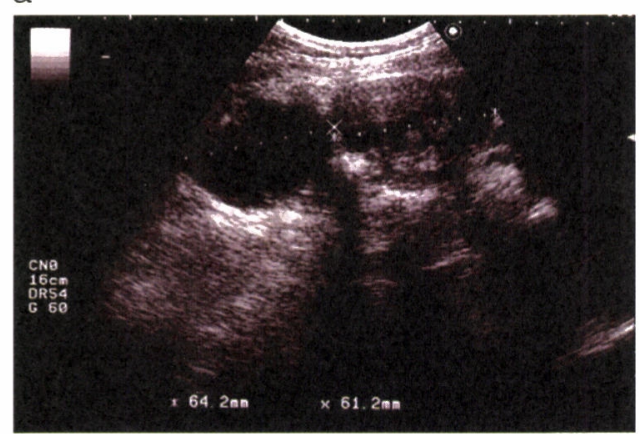

図2 症例 1

a. MRI 脂肪抑制 $T 1 W$

b. CT: 石灰化

a

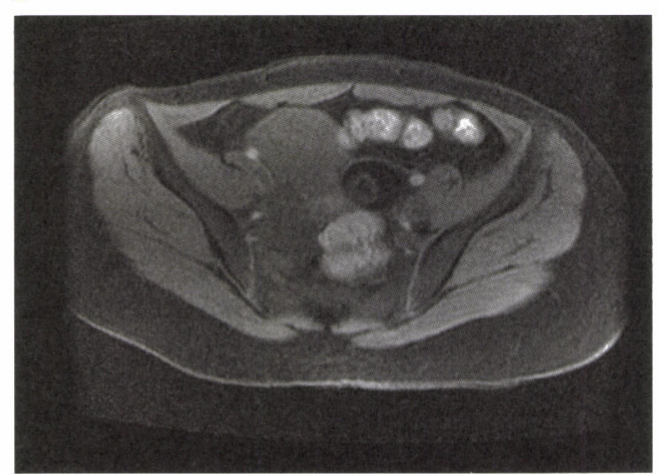

図 3 症例 1 の術中所見

a

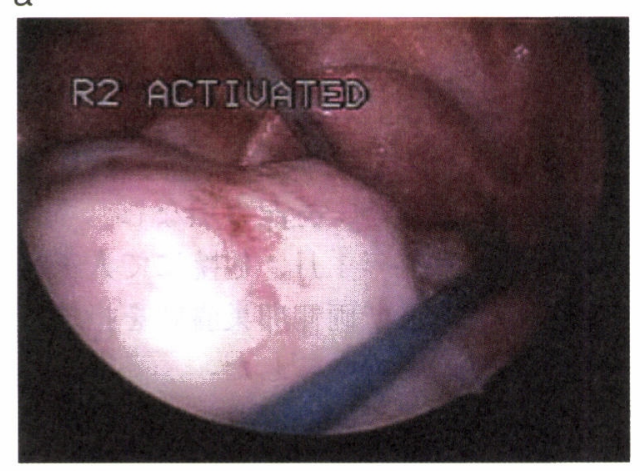

b

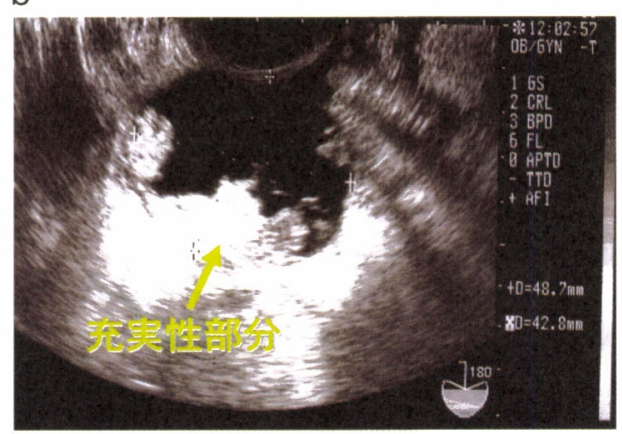

b

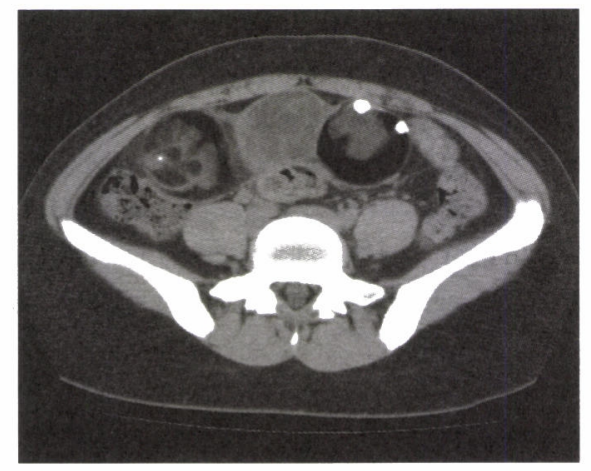

b

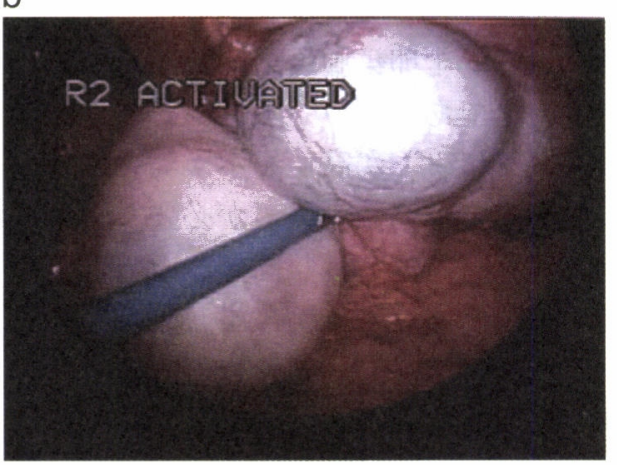


病理所見（図 4、5)：マクロでは腫瘍内容は脂 肪成分を含み、左卵巣には歯、骨、皮䖉、毛髪な ど成熟した組織が見られた。ミクロでは表皮, 脂 腺組織, 脳組織, 脂肪組織などから成り、囊胞内 面は角化型重層扁平上皮によって裹打ちされてい た。また呼吸上皮 (線毛円柱上皮), 気管支付属 腺等気管支構造も含んでいた。本症例でのSCC上 昇は腫瘍内での角化が充進していたためではない かと思われた。またCA19-9の上昇も気管支腺組織 からの分泌が原因と考えられた。

術後経過：腫瘍マーカーは術後 2 カ月でSCCを含 め全て正常化した。術後約 2 年後に膀胱炎のため 受診時に超音波で卵巣腫大を指摘され、MRIにて 右卵巣に約 $3 \mathrm{~cm} の$ dermoid cystの再発と診断、初 回手術から 2 年 6 ケ月後に腹腔鏡下に右卵巣腫瘍 摘出術を施行した。

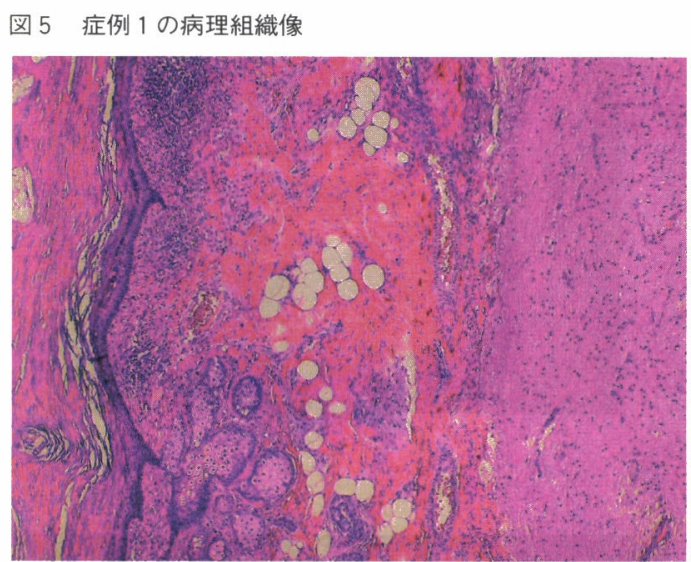

\section{症 例 2}

69 歳、 3 経妊 3 経産

主 訴：下腹部痛

既往歴：67歳時 腰椎圧迫骨折

家族歴：特記事項なし

現病歴：2005年 9 月に下腹部痛を自覚して前医を 受診、触診上約 $10 \mathrm{~cm}$ の腫瘍を認めMRIにて卵巣腫 瘍が疑われ当院紹介受診となった。

身体所見：身長 $141 \mathrm{~cm}$ 体重 $56.3 \mathrm{~kg}$ 、腹部は膨満し 左下腹部を中心に圧痛を認めた。

画像所見：MR I で左卵巣に T 1 強調 T 2 強調と も中等度〜高度高信号、脂肪抑制 T 1 強調像で信 号が抑制される多房性囊胞性腫瘤を認女左卵巣成 熟囊胞性奇形腫の茎捻転が疑われた。MRI、CTと もに腫瘍造影効果は認められなかった。また左卵 管に出血壊死を伴う所見も認められた。（図 6 )。 腫瘍マーカー：CA19-9 11698.0U/ml, CA125
図 4 症例 1 の摘出標本

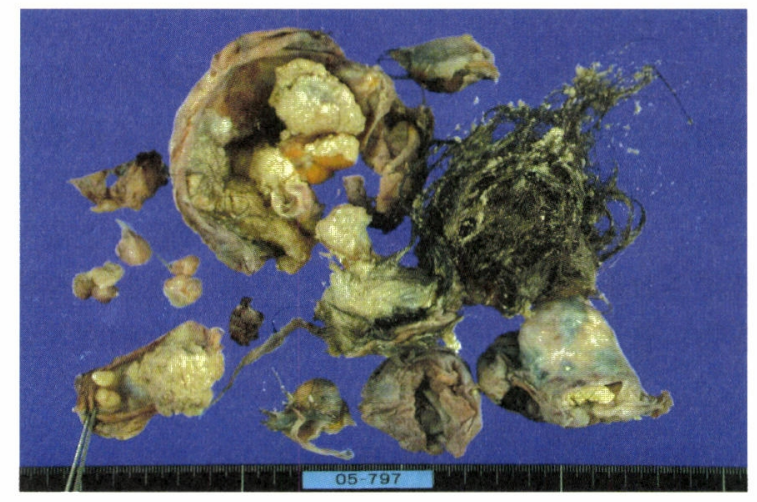

302.7U/ml, SCC 5.1ng/ml, CEA 43.9ng/ml 手術所見（図 7 ）：疼痛は軽隇していたが当院の MRIにて卵巣茎捻転が疑われたため受診当日に緊 急で腹腔鏡下付属器切除術を施行した。下腹部正 中 $2.5 \mathrm{~cm}$ 切開しトロッカーの挿入を試みたが、腹 膜が腫瘍と癒着しており腹腔内に到達できず、臍 より $5 \mathrm{~mm}$ トロッカーを挿入して腹腔鏡を開始し た。左右側腹部に $5 \mathrm{~mm}$ トロッカーを、下腹部正 中にwound retracterを装着した。Wound retracterにトロッカー抻入用の穴を開けた滅菌手 袋を装着して気腹を保った。腫瘍は膀胱子宮窩と 腸管に癒着していたが鈍的に剥離可能であった。 腫瘍は左卵巣原発で360度茎捻転していた。バイポ ーラーにて骨盤漏斗鞈帯、卵巣固有勒帯を凝固切 断した。エンドキャッチIIにて回収を試みたが腫 瘍が入らず、正中の切開創から腫瘍内容を吸引し 脂肪成分約 $500 \mathrm{ml}$ と毛髮 $60 \mathrm{~g}$ を摘出した後、腫瘍を 取り出した。内容液の腹腔内への漏出はなかった 
が毛髪摘出時に切開創面に一部付着した。右付属 器は肉眼的に異常なかったが合併切除した。緊急 手術となったため術中迅速病理組織診は実施でき なかった。

病理所見（図 8)：マクロでは左卵巣の単房性囊 胞内は毛髪と皮脂物で占められ、捻転による循環 障害のためほほ全域が灰黑色〜暗赤色調を呈して いた。ミクロでは内腔面は角化型重層扁平上皮で 被覆され脂腺組織、汗腺組織、毛囊組織腸管様構 造物、軟骨組織、骨組織、メラニン含有細胞等か

図 6 症例 2

a. MRI 脂肪抑制 $T 1 W \mid$

b. CT : 石灰化

a

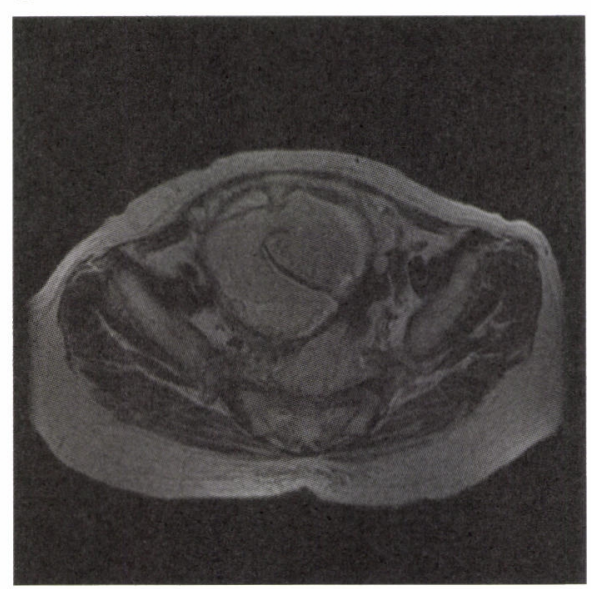

図 7 症例 2 の術中所見

a

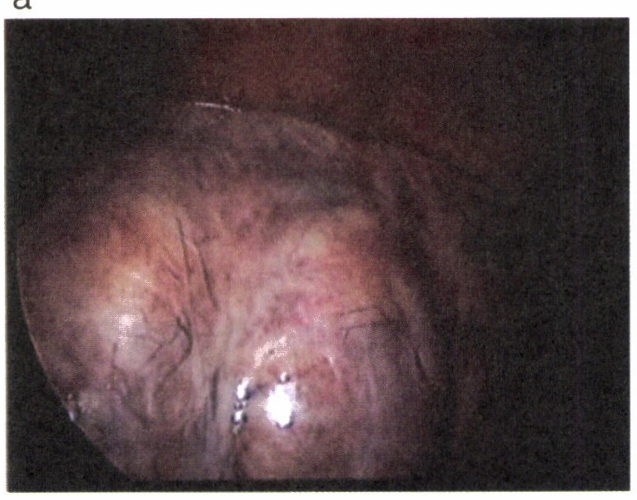

図 8 症例 2 の病理組織

a

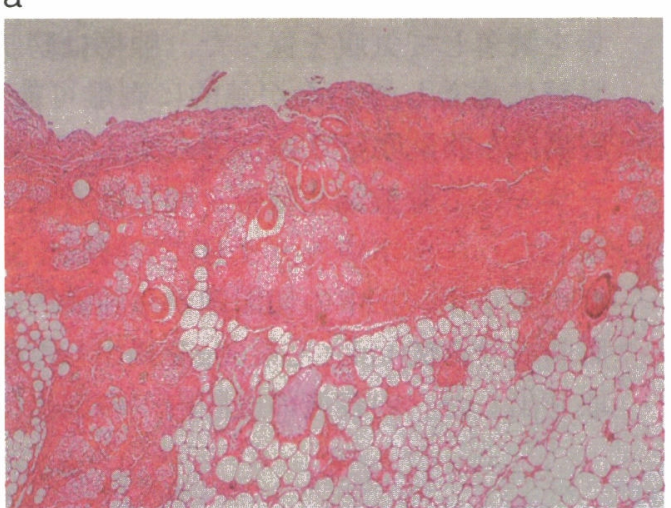

みられた。また循環障害のため凝固壊死、出血、 うっ血も認められた。術後経過：腫瘍マーカーは 術後 1 ケ月でCA19-9: 739.1U/ml, CA125: 58.2U/ml, SCC: $0.6 \mathrm{ng} / \mathrm{ml}$, CEA $4.9 \mathrm{ng} / \mathrm{ml}$ 、術後 2 ヶ月でCA199: $84.5 \mathrm{U} / \mathrm{ml}$, CA125: $11.6 \mathrm{U} / \mathrm{ml}$, SCC: $0.5 \mathrm{ng} / \mathrm{ml}$, CEA $1.1 \mathrm{ng} / \mathrm{ml}$ 、術後 3 ヶ月でCA19-9: 25.9U/ml, CA125: 9.3U/ml, SCC: $0.9 \mathrm{ng} / \mathrm{ml}, \mathrm{CEA}<1.0 \mathrm{ng} / \mathrm{ml}$ とCA $19-9$ 以外は1 カ月後には正常化した。CA19-9は正常す るのに 3 ケ月を要した。

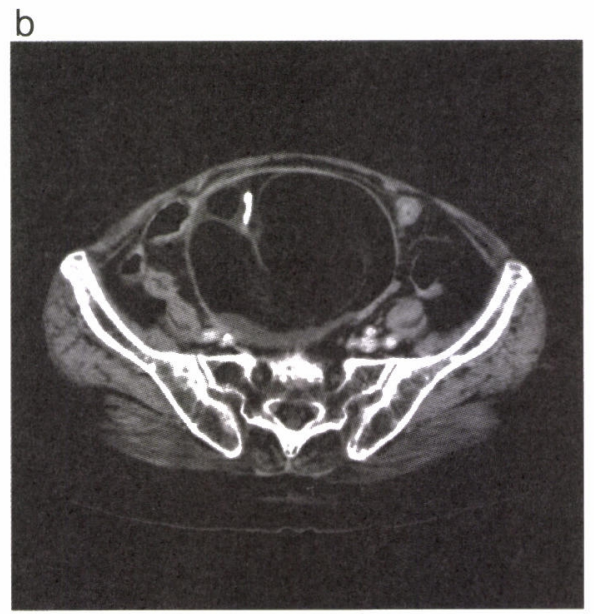

b

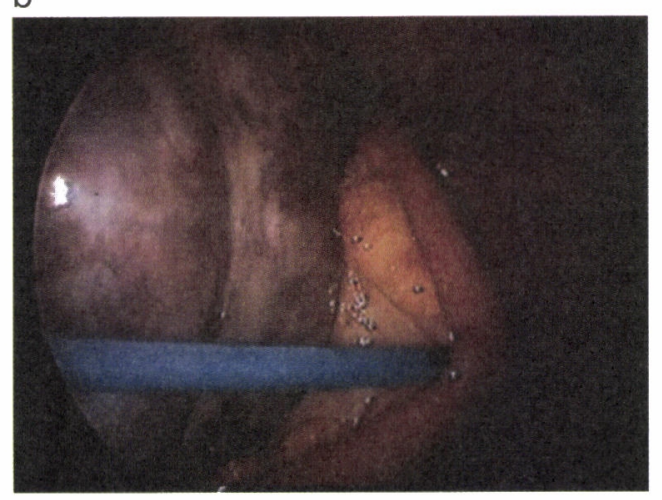

b

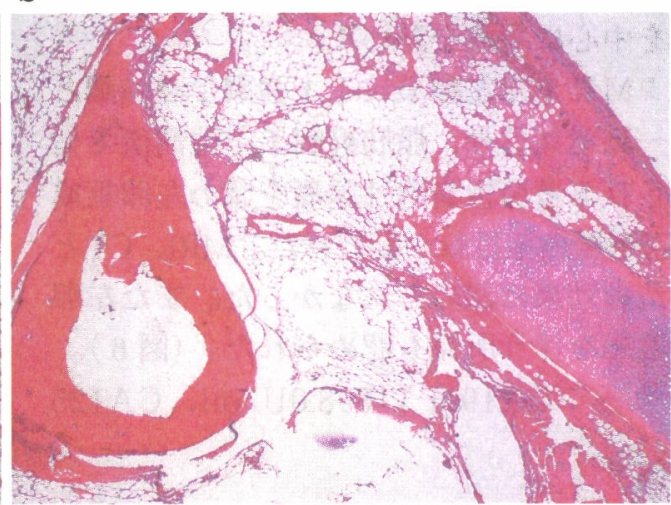




\section{考察}

成熟囊胞性奇形腫は頻度の高い良性卵巣腫瘍の 一つであり腹腔鏡下手術の適応となることが多い 疾患である。しかし 1 ～2\%に悪性転化すること が知られており ${ }^{1)}$ 術式を選択する場合は、術前に 墨性の可能性の有無について充分評価しておくこ とが重要である。成熟囊胞性奇形腫の悪性転化を 術前に予測する指標としては年齢、腫瘍マーカー、 腫瘍径、画像所見が挙げられる。

成熟囊胞性奇形腫においては様々な腫瘍マーカ 一が高值になることが知られており、最も陽性率 が高い腫瘍マーカーはCA19-9で単独陽性が大半と 報告されている ${ }^{2)}$ 。陽性率が高い理由として、 46XXの核型を有する肧細胞が単為生殖して各種 の胚葉成分に分化し、正常組織に類似した組織か らCA19-9が産生されるためと考えられている。扁 平上皮癌への悪性転化ではSCC值の上昇が重要と され ${ }^{3)}$ 、福田らは自験例と悪性転化報告例を検討 し、SCC $2.5 \mathrm{ng} / \mathrm{ml}$ 以上かつ年齢40歳以上をカット オフ值とすると悪性転化の的中率は鋭敏度 $76.9 \%$ 、 特異度 $96.3 \%$ となると報告している ${ }^{4)}$ 。症例 1 では 若年女性であったことと画像所見よりSCCがカッ トオフ值以上だったが良性の可能性が高いと判断 し腹腔鏡下手術を選択した。症例 2 は茎捻転を起こ し緊急手術となったため腫瘍マーカーの結果が判 明する前に画像所見を重視して術式を決定したが、 年齢、SCC值ともにカットオフ值を超えていた。 また 2 症例とも複数の腫瘍マーカーが陽性を示し 術前診断に苦慮したため腫瘍マーカーの評価につ いて再検討が必要と思われた。

悪性転化例の腫瘍の大きさでは新生児頭大、 $10 \mathrm{~cm}$ 以上が多いと言われており、悪性転化報告例 を手拳大、新生児頭大、小监頭大、成人頭大に分 類すると小览頭大以上のものが7割以上を占めると の報告もある。画像所見では初期症例は診断困難 とされているが、進行すると成熟囊胞性奇形腫の 壁に沿って充実部分が認められ、壁外進展や他臟 器や骨盤壁に浸潤傾向が認められるのが特徵的と されている ${ }^{5)}$ 。今回の症例ではそのような所見は 見られなかった。

卵巣腫瘍においては、本症例のようにSCCが高 値を示したために成熟囊胞性奇形腫の悪性転化を 否定しきれないもの以外にも術前に良性腫瘍と診 断し難い症例は日常臨床でしばしば経験される。 一方で術前に良性卵巣腫瘍と診断され腹腔鏡下手 術を施行した症例のうち $1 〜 2 \% に$ 悪性腫瘍を認め
るとの報告もある ${ }^{6)}$ 。

卵巣悪性腫瘍に対する腹腔鏡下手術の適応につ いて未だコンセンサスが得られていないため、術 式の選択には術前の良悪診断の精度を高めること が重要なのは言うまでもない。しかしながら腹腔 鏡下手術が広く普及し良性卵巣腫瘍に対し大多数 の施設で腹腔鏡下手術が選択されるようになった 現在、術前に良性腫瘍と診断される卵巣腫場にあ る一定の頻度で悪性腫瘍を認めるのであれば腹腔 鏡下手術の問題点を解消することがさらに重要な 課題と考えられる。

現在悪性卵巣腫瘍に対する腹腔鏡下手術適応の コンセンサスが得られていない要因に術中被膜破 綻やPort-site metastasisの問題が挙げられる。そ のためこれらの問題への対策は良性卵巣腫瘍を扱 う場合にも充分考慮されるべきである。前者につ いては開腹手術と腹腔鏡下手術での術中被膜破綻 の頻度に大差はないとの報告もあり腫瘍周囲の癒 着や腫瘍径、術者の技術にも左右される。対策と して腫瘍核出時は無理な体内法を避け体外法を選 択し迅速病理診断を行うこと、付属器切除時は回 収袋に捕捉可能な症例では切除後速やかに回収袋 に回収、捕捉不可であれば内容液を漏出させるこ となく吸引してから付属器切除後速やかに回収袋 に回収することが重要である。また術中被膜破綻 した場合には多量の洗浄液で腹腔内を洗浄し、術 後永久標本の診断で境界悪性腫瘍〜悪性腫瘍の結 果であればstaging surgery、化学療法の追加につ いて検討する必要がある。Port-site metastasisに ついてはこれまでに多くの症例報告があり ${ }^{7-10)}$ 、炭 酸ガスの暴露が腫瘍細胞の増殖に影響を与える可 能性が示唆されている ${ }^{11)}$ 。その発生機序は不明で あるが手術創部に腫瘍細胞が付着した後に影響が 及ぶとすれば、手術創部と㨂入されたトロッカー への腫瘍細胞の接触を回避するべきである。

術前診断で悪性が否定できない症例に対しても 安全な腹腔鏡下手術を完遂するために今後も更な る症例検討や技術の向上が必要である。

『本論文の要旨は第45回日本産科婦人科内視鏡学会 において発表した』

\section{参考文献}

1 ） 曰井直行、他：類皮囊胞腫の悪性変化、産と婦、1991; 58: 466-474.

2 ）牧野田知、他: 卵巣類皮豊胞腫における各種腫瘍マー カー值、㦃婦人科の実際、1991; 40: 99-104. 
3 ) Tomomi Yoshioka, Toshinobu Tanaka: Immunohistochemical and Molecular Studies on Malignant Transformation in Mature Cystic Teratoma of the ovary. J obstet Gynaecol Res. 1998; 24: 83-90.

4 ) 福田貴則、他：血清SCC異常高值を示し特異な形態を とったdermoid cystの一例、日産婦東京会誌、2003; 52: 218-221.

5 ) Kido A et al.: Dermoid cysts of the ovary with malignant transformation;MR appearance. AJR Am J Roentgenol. 1999; 172: 445-449

6 ) Havrilesky LJ et al.: Predictors of clinical outcomes in the laparoscopic management of adnexal masses. Obstet Gynecol. 2003; 102(2): 243-251.

7 ) Gleeson NC et al:: Abdominal wall metastases from ovarian cancer after laparoscopy. Am J Obstet Gynecol.1993; 169: 522-523

8 ) Maiman M, et al: Laparoscopic excision of ovarian neoplasms subsequently found to be malignancy. Obstet Gynecol. 1991; 77: 563-565

9 ) Hopkins MP, et al.: Laparoscopic port site implantation with ovarian cancer. Am J Obstet Gynecol. 2000; 182: 735-736

10) Huang KG, et al.: Management of port-site metastasis after laparoscopic surgery for ovarian cancer. Am J Obstet Gynecol. 2003; 189: 16-21

11) Smidt VJ, et al.: Effect of carbon dioxide on human ovarian carcinoma cell growth. Am J Obstet Gynecol. 2001; 185: 1314-1317 